\title{
Retrofitting of shear strength self-compacting reinforced concrete deep beams with FRP
}

\author{
Nabeel Al-Bayati, ${ }^{1,}$, Bassman Muhammad ${ }^{1}$ and Sarah Sadkhan ${ }^{1}$ \\ ${ }^{1}$ Building and Construction Engineering Department, University of Technology, Baghdad, Iraq
}

\begin{abstract}
Experimental program were carried out to investigate the behavior of self-compacting reinforced concrete deep beams retrofitting with carbon fiber reinforced polymer (CFRP). Six simply supported deep beams were tested under symmetrically two point loads, three beams were tested up to failure without strengthening as a control beams with different shear span to effective depth ratio $(a / d)$ while the other two beams were loaded up to $60 \%$ from the ultimate load of control beams for each a/d ratio and then retrofitted by the same configuration of CFRP to study the effect of a/d ratio on the properties of deep beams retrofitted. a/d for tested beams were $(0.8,1,1.2)$. Study was focused on determining failure loads, cracking loads, failure modes, load midspan deflection. All the beams had the same compressive strength, overall dimensions and flexural and shear reinforcement. It was concluded that using this retrofitted method is very efficient and a gain in the ultimate load capacity of the deep beams was obtained also the results showed that when a/d ratio increase from 0.8 to 1.2 , the ultimate load was decrease by $25 \%$ and midspan deflection was increased approximately at all load stages for control and retrofitted beams.
\end{abstract}

\section{Introduction}

A reinforced concrete deep beam is a structural element which has useful applications in many structures such as transfer girders and pile caps. Deep beams usually have a large depth, narrow width and contain congested shear reinforcement so that, the use of Traditional Vibrated Concrete in such beams may results in many problems like voids, segregation, and holes on the surface of the member. Therefore, it is expected that the selfcompacting concrete (SCC) is suitable for casting of deep beams. This particular type of concrete is different from vibrated concrete by its ability to fill completely the formwork and achieve full compaction due to selfweight only without segregation, even in the existence of congested reinforcement. During the service life, reinforced concrete structures often experience improvement and modification of their performance. The main contributing factors are change in their use, new design standards etc. In such circumstances there are two possible solutions: replacement, or strengthening or retrofit. The replacement of the full structure may have many disadvantages such as higher labor and material costs. When possible, it is better to strengthen or repair the structures (Mohammed, 2016).There are many ways to rehabilitation of reinforced concrete deep beams. Adding new concrete jacket with additional reinforcement, using external steel sections, and wrapping the section with Fiber-reinforced polymers, FRP are the most popular methods of strengthening and retrofitting concrete beams. A Fiber Reinforced Polymer (FRP) composite is defined as a polymer matrix that is reinforced with a fiber with a sufficient aspect ratio to provide a distinguishable reinforcing function. In the last decade, the investigation on the behavior of reinforced concrete structures retrofitted by FRP has become a very important research field. The shear behavior depends on the detailing and type of shear reinforcement, size of the element, the position and type of applied loading and the shear resistance capacity of concrete. External shear strengthening using FRP composites has become very popular due to several reasons including ease of application, lightweight feature and aesthetic appearance (Rasheed 2016).

\section{Experimental program}

*Corresponding author: 40063@uotechnology.edu.iq 
In this study, six deep beams were tested to investigate the influence of a/d ratio on the behavior of SCC deep beams retrofitted with CFRP with special attention to cracking and ultimate load, vertical mid-span deflection and modes of failure. All the specimens had a length of $1400 \mathrm{~mm}$, height $\mathrm{h}$ of $400 \mathrm{~mm}$ and width $\mathrm{b}$ of $150 \mathrm{~mm}$ were constructed and tested under symmetrically two points top loading as shown in Figure 1. To investigate the effect of a/d ratio, all the beams retrofitting with the same configuration of CFRP, consisting of one layer of five carbon fiber strips and orthogonal to the load path that joining load and support points as presented in Figure 2

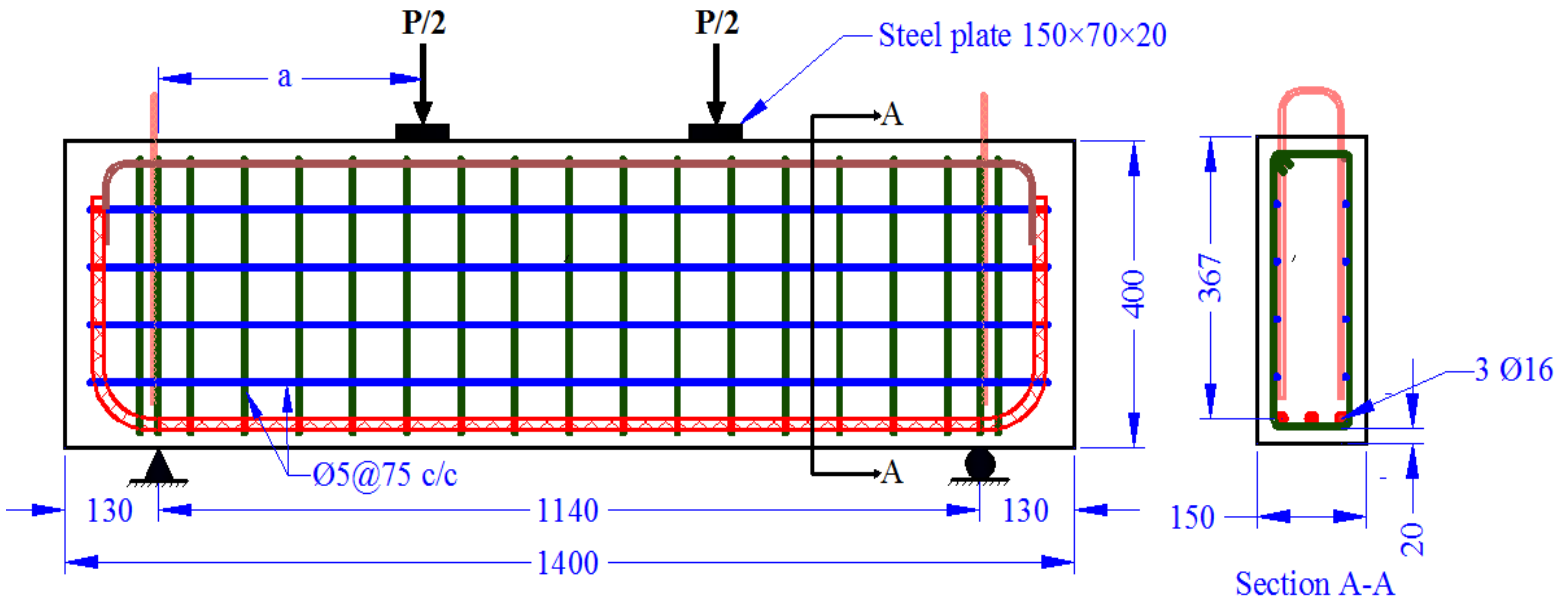

Fig. 1 Specimens details and arrangement of reinforcement, note: All dimensions in $\mathrm{mm}$

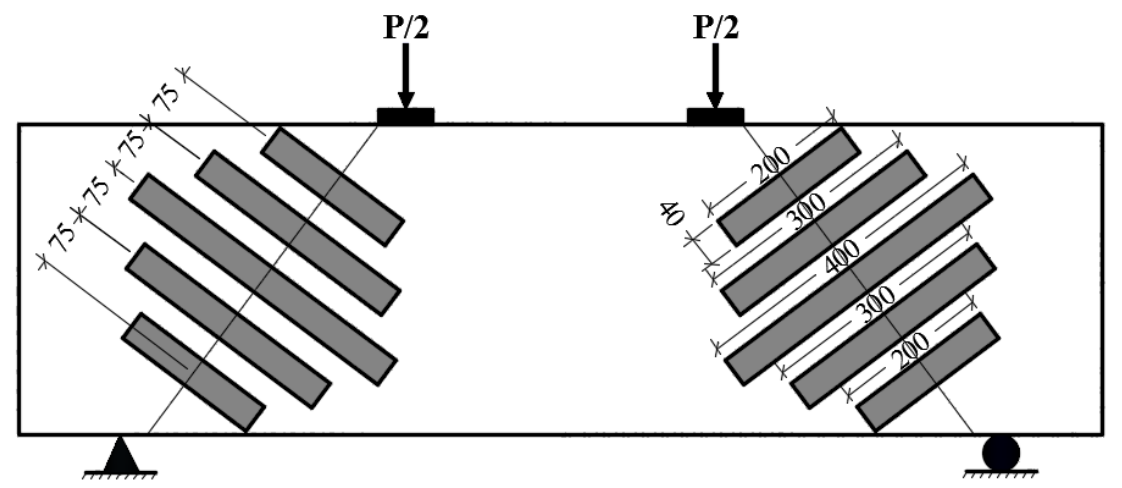

Fig. 2 CFRP details

\section{Concrete mixes}

Several trial mixes have been made in accordance with the recommendations of (EFNARC, 2002). Mix design of SCC must meet the specification of segregation resistance and filling ability. Details of the adopted SCC mixture are shown in Table 1. To ensure the used concrete is self-compacting, Slump Flow, T50, L-box and V-funnel tests were performed. Furthermore, the results were compared with the limitation of (EFNARC, 2002) and (ACI 237R-07) as indicated in Table 2.

Table 1 SCC mix proportions

\begin{tabular}{|c|c|c|c|c|c|c|}
\hline $\begin{array}{c}\text { Cement } \\
\left(\mathbf{k g} / \mathbf{m}^{\mathbf{3}}\right)\end{array}$ & $\begin{array}{c}\text { Limestone } \\
\text { Powder } \\
\left(\mathbf{k g} / \mathbf{m}^{\mathbf{3}}\right)\end{array}$ & $\begin{array}{c}\text { Water } \\
\left(\mathbf{k g} / \mathbf{m}^{\mathbf{3}}\right)\end{array}$ & $\begin{array}{c}\mathbf{W} / \mathbf{p} \\
\text { By weight }\end{array}$ & $\begin{array}{c}\text { Coarse } \\
\text { aggregate } \\
\left(\mathbf{k g} / \mathbf{m}^{\mathbf{3}}\right)\end{array}$ & $\begin{array}{c}\text { Fine } \\
\text { aggregate } \\
\left(\mathbf{k g} / \mathbf{m}^{\mathbf{3}}\right)\end{array}$ & $\begin{array}{c}\text { Super } \\
\mathbf{p l a s t i c i z e r} \\
\left(\mathbf{l} / \mathbf{m}^{\mathbf{3}}\right)\end{array}$ \\
\hline 350 & 175 & 180 & 0.34 & 767 & 797 & $4.9^{*}$ \\
\hline
\end{tabular}

\footnotetext{
* 1.4 liter/100 kg cement
} 
Table 2 Fresh SCC test results

\begin{tabular}{|c|c|c|c|}
\hline Test method & Result & EFNARC (2002) Limits & ACI 237R-07 Limits \\
\hline Slump flow $(\mathrm{mm})$ & 720 & $650-800$ & $450-760$ \\
\hline $\mathrm{T}_{500}(\mathrm{sec})$ & 3 & $2-5$ & $2-5$ \\
\hline L-box $\left(\mathrm{H}_{2} / \mathrm{H}_{1}\right)$ & 0.9 & $0.8-1$ & $0.8-1$ \\
\hline V-funnel $(\mathrm{sec})$ & 10 & $6-12$ & - \\
\hline
\end{tabular}

\section{Materials}

1. Cement: an ordinary Portland cement (type I) was used throughout this research. Test results complying with ASTM Iraqi standards specifications (IQS No.5, 1984). Table 3 and 4 show chemical composition and Physical properties of cement respectively. These tests were conducted by the National Center for Constructional Laboratories and Research.

2. Fine Sand: Natural sand was used. The results obtained showed that the sand used was within the requirement of specifications and (IQS No.45, 1984). Table 5 and 6 show Grading and Physical properties of fine aggregate. These tests were performed by the researcher at the laboratories of the University of Technology and National Center for Constructional Laboratories and Researches respectively.

3. Coarse aggregate: Crushed gravel with a maximum size of $14 \mathrm{~mm}$ used throughout this work. Test results showed that the sulfate content and grading of coarse aggregate conforms to the Iraqi specification (IQSNo.45, 1984). Table 7 and 8 show Grading and Physical properties of fine aggregate. These tests were performed by the researcher at the laboratories of the University of Technology and National Center for Constructional Laboratories and Researchers respectively.

4. Limestone Powder: Limestone powder (LSP) was used as a filler material for self- compacting concrete. The increased of fine materials will improve its cohesiveness and enhance the resistance to segregation. Table 9 show chemical composition of limestone powder. These tests were conducted by the National Center for Constructional Laboratories and Research.

5. Superplasticizer: to produce, self- compacting concrete, a superplasticizer which named commercially as SikaVicoCrete-5930 was used. SikaVicoCrete-5930 is appropriate with all Portland cement types and adding it to the mix leads to a significant increase in slump without segregation. Table (10) shows Properties of superplasticizer according to manufacturer data sheet.

6. Carbon, Fiber (CFRP): beams were externally retrofitted using SikaWrap ${ }^{\circledR}-300 \mathrm{C} / 60$ woven carbon fiber fabric for strengthening of structures. The orientation angle of the fabric is equal to $0^{\circ}$, unidirectional. Table (11) indicates the technical description of CFRP. According to manufacturer data sheet.

7. Bonding Materials: Sikadur ${ }^{\circledR}-330$ is the most adequate adhesive material for carbon fiber fabric is which consists from two parts. Table (12) shows the Properties of the used adhesive material according to manufacturer data sheet.

8. Steel reinforcement: Deformed steel bars of a diameter $16 \mathrm{~mm}$ and $5 \mathrm{~mm}$ were used for tension reinforcement and shear reinforcement (vertical and horizontal) respectively. Three samples were prepared for each type for tensile tests to obtain their yield strength, ultimate strength and elongation percentage. The test was conducted at the Laboratories of University of Technology. Test results obtained are given in Table 13. The results showed that the steel reinforcement meet to the requirements of the ASTM A1064-14 and ASTM A615-16. Figure1 show the reinforcement details for the beams.

Table 3 Chemical Composition of Cement

\begin{tabular}{|l|c|c|c|}
\hline \multicolumn{1}{|c|}{ Compound composition } & Chemical composition & \% By Weight & IQS 5/1984 \\
\hline lime & $\mathrm{CaO}$ & 61 & - \\
\hline Silica & $\mathrm{SiO}_{2}$ & 21.1 & - \\
\hline Alumina & $\mathrm{Al}_{2} \mathrm{O}_{3}$ & 4.64 & - \\
\hline Iron Oxide & $\mathrm{Fe}_{2} \mathrm{O}_{3}$ & 4.2 & - \\
\hline Magnesia & $\mathrm{MgO}$ & 1.51 & $\leq 5$ \\
\hline sulfate & $\mathrm{SO}_{3}$ & 2.35 & $\leq 2.8$ \\
\hline Loss on ignition & $\mathrm{L.O.I}$ & 2.79 & $\leq 4$ \\
\hline Insoluble residue & $\mathrm{I} . \mathrm{R}$ & 0.5 & $\leq 1.5$ \\
\hline Lime saturation factor & $\mathrm{L} . \mathrm{S} . \mathrm{F}$ & 0.88 & $0.66-1.02$ \\
\hline Tricalcium Silicate & $\mathrm{C}_{3} \mathrm{~S}$ & 44 & - \\
\hline Dicalcium Silicate & $\mathrm{C}_{2} \mathrm{~S}$ & 27.4 & - \\
\hline Tricalcium Aluminate & $\mathrm{C}_{3} \mathrm{~A}$ & 5.2 & - \\
\hline Tetracalcium Alumminoferrite & $\mathrm{C}_{4} \mathrm{AF}$ & 12.77 & - \\
\hline
\end{tabular}


Table 4 Physical Properties of the Cement

\begin{tabular}{|l|c|c|c|}
\hline \multicolumn{1}{|c|}{ Physical Properties } & Units & Test Result & IQS 5/1984 \\
\hline $\begin{array}{l}\text { Fineness using Blaine air permeability } \\
\text { apparatus }\end{array}$ & $\mathrm{m}^{2} / \mathrm{kg}$ & 384 & $\geq 230$ \\
\hline $\begin{array}{l}\text { Setting Time (Vicat's Method) } \\
\text { Initial }\end{array}$ & $\begin{array}{c}\text { Minutes } \\
\text { Final }\end{array}$ & 120 & $\geq 45 \mathrm{~min}$ \\
\hline Soundness using autoclave method & $\%$ & 0.25 & $\leq 10 \mathrm{hrs}$ \\
\hline Compressive strength for cement paste & & & $\leq 0.8$ \\
cube mold (50 mm) at: & $\mathrm{MPa}$ & 22 & \\
3 days & $\mathrm{MPa}$ & 26.5 & $\geq 15$ \\
7 days & & & \\
\hline
\end{tabular}

Table 5 Grading of Fine Aggregate

\begin{tabular}{|c|c|c|}
\hline $\begin{array}{c}\text { Sieve Size } \\
(\mathbf{m m})\end{array}$ & $\begin{array}{c}\text { \% passing by } \\
\text { weight }\end{array}$ & $\begin{array}{c}\text { IQS 45/1984 } \\
\text { Zone (2) }\end{array}$ \\
\hline 10 & 100 & 100 \\
\hline 4.75 & 97.5 & $90-100$ \\
\hline 2.36 & 92.7 & $75-100$ \\
\hline 1.18 & 77.8 & $55-90$ \\
\hline 0.60 & 48.7 & $35-59$ \\
\hline 0.30 & 19 & $8-30$ \\
\hline 0.15 & 4.2 & $0-10$ \\
\hline
\end{tabular}

Table 6 Physical Properties of Fine Aggregate

\begin{tabular}{|l|c|c|}
\hline \multicolumn{1}{|c|}{ Physical Properties } & $\begin{array}{c}\text { Test } \\
\text { Results }\end{array}$ & $\begin{array}{c}\text { IQS } \\
\mathbf{4 5 / 1 9 8 4}\end{array}$ \\
\hline Specific Gravity & 2.58 & - \\
\hline Sulfate Content \% & 0.14 & $\leq 0.5$ \\
\hline Absorption \% & 0.75 & - \\
\hline
\end{tabular}

Table 7 Grading of Coarse Aggregate

\begin{tabular}{|c|c|c|}
\hline $\begin{array}{c}\text { Sieve Size } \\
(\mathbf{m m})\end{array}$ & $\begin{array}{c}\text { \% passing by } \\
\text { weight }\end{array}$ & IQS 45/1984 \\
\hline 20 & 100 & 100 \\
\hline 14 & 100 & $90-100$ \\
\hline 10 & 78 & $50-85$ \\
\hline 5 & 3.8 & $0-10$ \\
\hline
\end{tabular}

Table 8 Physical Properties of Coarse Aggregate

\begin{tabular}{|l|c|c|}
\hline \multicolumn{1}{|c|}{ Physical Properties } & $\begin{array}{c}\text { Test } \\
\text { Results }\end{array}$ & $\begin{array}{c}\text { IQS } \\
\mathbf{4 5 / 1 9 8 4}\end{array}$ \\
\hline Specific Gravity & 2.64 & - \\
\hline Sulfate Content \% & 0.05 & $\leq 0.1$ \\
\hline Absorption \% & 0.72 & - \\
\hline
\end{tabular}

Table 9 Chemical Composition of Limestone Powder

\begin{tabular}{|c|c|}
\hline Oxide Composition & \% By Weight \\
\hline $\mathrm{CaO}$ & 54.3 \\
\hline $\mathrm{SiO}_{2}$ & 1.40 \\
\hline $\mathrm{Al}_{2} \mathrm{O}_{3}$ & 0.71 \\
\hline $\mathrm{Fe}_{2} \mathrm{O}_{3}$ & 0.14 \\
\hline $\mathrm{MgO}$ & 0.12 \\
\hline $\mathrm{SO}_{3}$ & 0.23 \\
\hline $\mathrm{L} . \mathrm{O} . \mathrm{I}$ & 42.64 \\
\hline
\end{tabular}

Table 10 Properties of Superplasticizer

\begin{tabular}{|l|l|}
\hline \multicolumn{1}{|c|}{ Form } & \multicolumn{1}{c|}{ Liquid } \\
\hline Color & Turbid liquid \\
\hline Relative Density & $1.08 \mathrm{Kg} / 1 \pm 0.005$ \\
\hline Boiling & $100{ }^{\circ} \mathrm{C}$ \\
\hline Specific Gravity & $1.08 \pm 0.005 \mathrm{Kg} / 1$ \\
\hline $\mathrm{pH}$ & $7-9$ \\
\hline Normal dosage & $0.8-2 \%$ \\
\hline Chlorides & Free from chloride \\
\hline Transport & Non-hazardous \\
\hline
\end{tabular}

Table 11 The Technical Properties of CFRP

\begin{tabular}{|l|c|}
\hline \multicolumn{1}{|c|}{ Properties } & $\begin{array}{c}\text { Sika Warp }{ }^{\circledR}- \\
\mathbf{3 0 0 ~ C / 6 0}\end{array}$ \\
\hline Tensile Strength (MPa) & 3900 \\
\hline E-Modulus (MPa) & 230000 \\
\hline Elongation At Break (strain)\% & 1.5 \\
\hline Thickness (mm) & 0.166 \\
\hline Areal Weight $\left(\mathrm{g} / \mathrm{m}^{2}\right)$ & $300 \pm 15$ \\
\hline Density $\left(\mathrm{g} / \mathrm{cm}^{3}\right)$ & 1.79 \\
\hline
\end{tabular}

Table 12 Properties of the Used Adhesive Material

\begin{tabular}{|l|l|}
\hline \multicolumn{1}{|c|}{ Properties } & \multicolumn{1}{c|}{ Sikadur $^{\circledR} \mathbf{- 3 3 0}$} \\
\hline $\begin{array}{l}\text { Density }(\mathrm{kg} / \mathrm{l}) \\
\text { at }+23^{\circ} \mathrm{C}\end{array}$ & Parts A+B mixed : 1.31 \\
\hline $\begin{array}{l}\text { Tensile strength } \\
(\mathrm{MPa})\end{array}$ & 30 \\
\hline E-Modulus (GPa) & $\begin{array}{l}\text { Flexural }: 3.8 \\
\text { Tensile }: 4.5\end{array}$ \\
\hline $\begin{array}{l}\text { Elongation At } \\
\text { Break (strain) } \%\end{array}$ & 0.9 \\
\hline $\begin{array}{l}\text { Setting Time } \\
\text { (Minute) at } 35^{\circ} \mathrm{C}\end{array}$ & 30 \\
\hline Mixing ratio & Part A:part B $=4: 1$ by weight \\
\hline
\end{tabular}

Table 13 Properties of the Reinforcing Steel Bars

\begin{tabular}{|c|c|c|c|}
\hline 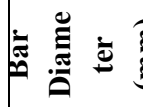 & 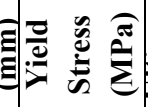 & 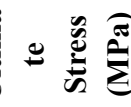 & 童 \\
\hline 5 & 558 & 643 & 5.6 \\
\hline 16 & 575 & 680 & 17 \\
\hline
\end{tabular}




\section{Results and discussion}

\subsection{Mechanical Properties of Hardened SCC}

Compressive, Strength ( $f^{\prime} \mathrm{c}$ ): in order to perform a compressive strength test, ASTM C39/C39M-05 procedure was followed by using three cylinders of $150 \times 300 \mathrm{~mm}$ at 28 days from each mix batch. Average compressive strength tests results were shown in Table 14.

Splitting, Tensile Strength, (fct): this test was carried out using three cylinders of $150 \times 300 \mathrm{~mm}$ for each batch mix according to ASTM C496/C496M -04 at 28 day. The concrete cylinder fails when a longitudinal crack breaks the cylinder into two halves test. Test results of average splitting tensile strength were shown in Table 14.

Flexural Strength (fr): The flexural strength of concrete had been determined according to ASTM C78-10. Three prisms of $100 \times 100 \times 400 \mathrm{~mm}$ was tested. Table 14 shows test results of average flexural strength.

Table 14 Mechanical Properties of SCC

\begin{tabular}{|c|c|c|c|}
\hline $\begin{array}{c}\text { Deep beam } \\
\text { Symbols }\end{array}$ & $\begin{array}{c}\boldsymbol{f}^{\prime} \mathbf{c} \\
(\mathbf{M P a})\end{array}$ & $\begin{array}{c}\boldsymbol{f}_{\text {ct }} \\
(\mathbf{M P a})\end{array}$ & $\begin{array}{c}\boldsymbol{f}_{\mathbf{r}} \\
(\mathbf{M P a})\end{array}$ \\
\hline $\begin{array}{c}\text { D-Control-0.8 } \\
\text { and DB-0.8 }\end{array}$ & 34.2 & 3.61 & 4.43 \\
\hline \hline D-Control-1 & 33.38 & 3.59 & 4.57 \\
\hline DB-1 & 32.75 & 3.72 & 4.6 \\
\hline $\begin{array}{c}\text { D-Control-1.2 } \\
\text { and DB-1.2 }\end{array}$ & 33.8 & 3.82 & 4.62 \\
\hline \hline average & 33.5 & 3.68 & 4.55 \\
\hline
\end{tabular}

Procedure and Instruments of Testing: The beams were tested using the universal testing machine (AVERY) of $2500 \mathrm{KN}$ capacity. midspan vertical deflection was recorded during the test. Also, First crack load and crack patterns were observed during the test. To prevent local crushing of concrete, bearing plates, placed at the loading points.

Behavior of Control Beams: The crack pattern and failure mode of the control beams are depicted in plate 1 . They were failed along the splitting line. The first shear cracks appeared in D-Control-0.8, DControl-1, D-Control-1.2 at a load $200 \mathrm{kN}, 160 \mathrm{kN}$ and $160 \mathrm{kN}$ respectively. After that many flexural and shear cracks were observed and the cracks become wider and longer with increasing of load. The collapse happened at a load of $800 \mathrm{kN}$ for DControl-0.8, 680kN for D-Control-1 and $640 \mathrm{kN}$ for D-Control-1.2. The results showed that the ultimate load decrease by $25 \%$ when a/d ratio increased from 0.8 to 1.2 . The control beam D-Control-0.8 shows maximum load and higher central deflection value at failure compare with other control beams. Figure 3 show the ultimate load and central deflection for control beams with different a/d ratios $(0.8,1$ and 1.2). This figure demonstrates that the deflection increase with the increase of $\mathrm{a} / \mathrm{d}$ ratio.

Behavior of Pre-cracking Beams: The beams D1-0.8, D3-1 and D1-1.2 were loaded to $60 \%$ of the ultimate load of control beams D-Control-0.8 D-Control-1and D-Control-1.2 respectively. Many shear and flexural cracks were noticed in both faces (front and rear) of beams as shown in plate 2 . The central deflection of these beams shows in Figure 4. They shows that their behavior similar to control beams behavior and the beam with a/d ratio equal to 1.2 have higher deflection than other beams. Table 15 shows first crack load in shear and flexural with the corresponding deflection. Also, it presents deflection at a load of $60 \%$ from control beam for pre-cracking deep beams.

Table 15 Experimental results for Pre-cracking beams

\begin{tabular}{|c|c|c|c|c|c|}
\hline $\begin{array}{c}\text { Deep beam } \\
\mathbf{s y m b o l s}\end{array}$ & $\begin{array}{c}\mathbf{P}_{\mathbf{c r}) \mathbf{s}} \\
\mathbf{k N}\end{array}$ & $\begin{array}{c}\boldsymbol{\Delta}_{\mathbf{c r}) \mathbf{s}} \\
\mathbf{m m}\end{array}$ & $\begin{array}{c}\mathbf{P}_{\mathbf{c r}) \mathbf{f}} \\
\mathbf{k N}\end{array}$ & $\begin{array}{c}\boldsymbol{\Delta}_{\mathbf{c r}) \mathbf{f}} \\
\mathbf{m m}\end{array}$ & $\begin{array}{c}\boldsymbol{\Delta}_{\mathbf{6 0} \%} \\
\mathbf{m m}\end{array}$ \\
\hline $\begin{array}{c}\text { D-control- } \\
0.8\end{array}$ & 200 & 1.57 & 180 & 1.43 & 3.72 \\
\hline D1-0.8 & 200 & 1.61 & 160 & 1.25 & 3.73 \\
\hline \hline D-control-1 & 160 & 1.37 & 160 & 1.37 & 3.56 \\
\hline D3-1 & 140 & 1.16 & 160 & 1.35 & 3.34 \\
\hline \hline D-control- \\
1.2 & 160 & 1.67 & 200 & 2.35 & 3.75 \\
\hline D1-1.2 & 140 & 1.4 & 120 & 1.18 & 3.72 \\
\hline
\end{tabular}

\subsection{Behavior of the retrofitted beam (D1R-I- 0.8, D3R-I-1, D1R-I-1.2)}

Crack pattern and failure modes: The crack pattern and failure mode of the retrofitted beams are depicted in plates 3 . The retrofitting beams show a rise in ultimate load compare with reference beams for all a/d ratios. The beams D1R-I-0.8, D3R-I-1, D1R-I-1.2 failed at loads of $980 \mathrm{kN}, 820 \mathrm{kN}$ and $720 \mathrm{kN}$ respectively which gives increase in ultimate load by $22.5 \%, 20.5$ and 12.5 respectively compared with control beams. For the retrofitting beams, the reduction in ultimate load capacity with increase a/d ratio from 0.8 to 1.2 was about $36 \%$. The failure loads of the beams in third group were higher than 
those of the corresponding beams of other groups because of the shorter shear span length. The mode failure of beam D1R-I-0.8 was by de-bonding of CFRP strips at the roller side and crashing the concrete near the load point. While D3R-I-1 failed by tearing the middle strip at the right side of the beam followed by de-bonding the other strips in the same side.
It can be noticed that the failure mode D1R-I-1.2 was shear compression failure happened by debonded of CFRP as well as crushing of concrete at compression zone so a large piece of concrete was pulled up at this zone and take off the upper carbon fiber strip at the left side of the beam. Test results of beam specimens are shown in Table 16.

Table 16 Experimental results of beam specimens

\begin{tabular}{|c|c|c|c|c|c|c|c|c|c|c|}
\hline \multirow[b]{2}{*}{ Beam symbols } & \multirow[b]{2}{*}{$\mathbf{a} / \mathbf{d}$} & \multicolumn{2}{|c|}{ Shear force } & \multicolumn{2}{|c|}{ Flexural Force } & \multicolumn{2}{|c|}{$\begin{array}{l}\text { Ultimate } \\
\text { force }\end{array}$} & \multirow{2}{*}{$\begin{array}{c}\% \\
\text { Increasing } \\
\text { in } \\
\text { Ultimate } \\
\text { Load }\end{array}$} & \multirow{2}{*}{ 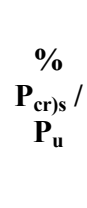 } & \multirow{2}{*}{$\begin{array}{c}\text { Modes of } \\
\text { failure }\end{array}$} \\
\hline & & $\begin{array}{l}\mathbf{P}_{\mathrm{cr}) \mathrm{s}} \\
\mathbf{k N}\end{array}$ & $\begin{array}{l}\Delta_{\text {cr)s }} \\
\text { mm }\end{array}$ & $\begin{array}{l}\mathbf{P}_{\text {cr)f }} \\
\mathbf{k N}\end{array}$ & $\begin{array}{l}\Delta_{\text {cr)f }} \\
\text { mm }\end{array}$ & $\begin{array}{l}\mathbf{P}_{\mathbf{u}} \\
\mathbf{k N}\end{array}$ & $\begin{array}{c}\Delta_{\mathbf{u}} \\
\mathbf{m m}\end{array}$ & & & \\
\hline D-Control- 0.8 & 0.8 & 200 & 1.57 & 180 & 1.43 & 800 & 7.17 & - & 25 & DS \\
\hline D1R-I-0.8 & 0.8 & 180 & 1.28 & 200 & 1.44 & 980 & 7.62 & 22.5 & 18 & $\begin{array}{c}\text { FRPD }+C \\
C\end{array}$ \\
\hline D-Control-1 & 1 & 160 & 1.37 & 160 & 1.37 & 680 & 6.53 & - & 23 & DS \\
\hline D3R-I-1 & 1 & 200 & 1.7 & 160 & 1.35 & 820 & 7.19 & 20.5 & 24 & $\begin{array}{c}\text { FRPD }+F R \\
\text { PT }\end{array}$ \\
\hline D-Control-1.2 & 1.2 & 160 & 1.67 & 200 & 2.35 & 640 & 6.8 & - & 25 & DS \\
\hline D1R-I-1.2 & 1.2 & 160 & 1.32 & 180 & 1.5 & 720 & 7.15 & 12.5 & 22 & $\begin{array}{c}\text { FRPD }+C \\
C\end{array}$ \\
\hline
\end{tabular}

Load mid-span deflection responses: The ultimate load and mid-span vertical deflection for all the beams are illustrated at Table 16. The load-deflection relationship for the control and retrofitting beam for the three groups are shown in Figure 5 to 7 . it is noticeable from this figures the effect of CFRP on decreasing the deflection value for retrofitting beams in compare with control ones. Figure 8 shows the deflection of the retrofitting beams with different $\mathrm{a} / \mathrm{d}$ ratio. It present that the deflection increase with the increase of a/d ratio. Similar to control beams, the retrofitted beam D1R-I-0.8 shows maximum load and higher central deflection value at failure compare with other retrofitted beams. The adopted retrofitting arrangement is identical in the three beams to allow for studying the effect of composite action on the retrofitting of reinforced concrete deep beams in case of changing a/d ratios.

\section{Conclusions}

According to the experimental results of retrofit deep beams by using CFRP with different a/d ratio, the following conclusion can be recorded:

1. All the tested beams failed in shear, the failure mode of control beams was diagonal splitting failure along the line joining the load and support while retrofitted beams failed by combination many modes of failure such as deponding or tearing of CFRP as well as crushing of concrete.

2. All retrofitted deep beams given an increase in ultimate strength with represents to reference model.

3. For All a/d ratios, retrofitted deep beams showed reduction in deflection values in compare with control beams.

4. In general, the behavior of beams tested influenced by $\mathrm{a} / \mathrm{d}$ ratio. It was found that the increase of a/d ratio from 0.8 to 1.2 decreases the failure load for control and retrofitted beams by about $25 \%$ and $36 \%$ respectively.

5. midspan deflection decrease with increase a/d ratio for control and retrofitted beams. 


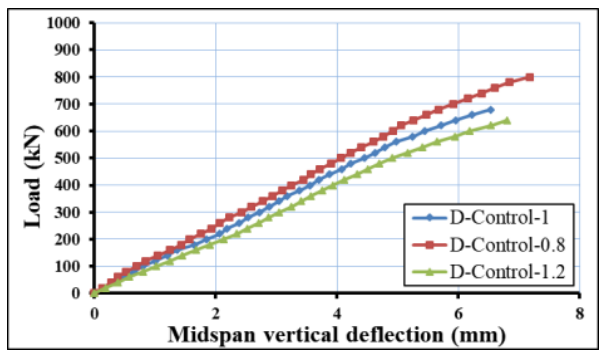

Figure 3 Load-deflection relationship for control deep beams

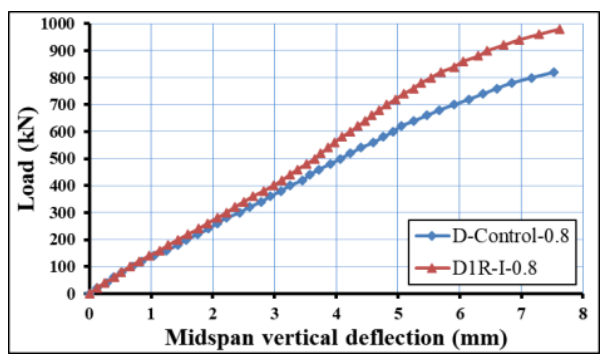

Figure 4 Load-deflection relationship for pre-cracking deep beams

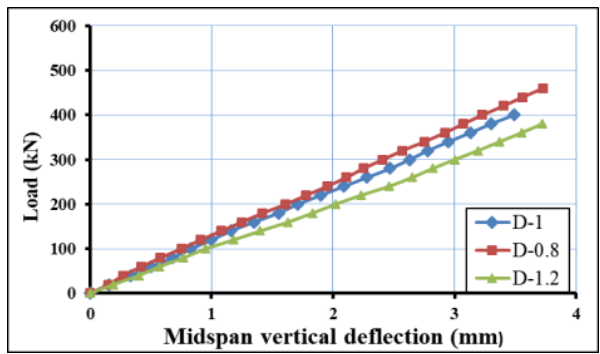

Figure 5 Load-deflection relationship for D-Control-0.8 and D1R-R-0.8

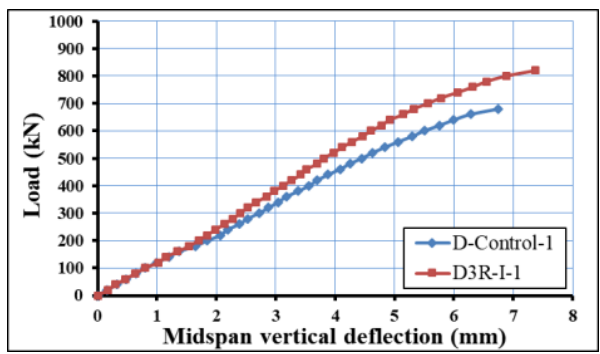

Figure 6 Load-deflection relationship for D-Control-1 and D3RI-I-1

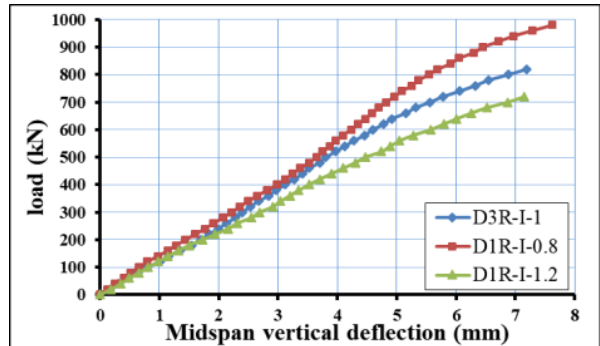

Figure 7 Load-deflection relationship for D-Control-1.2 and D3RI-I-1.2

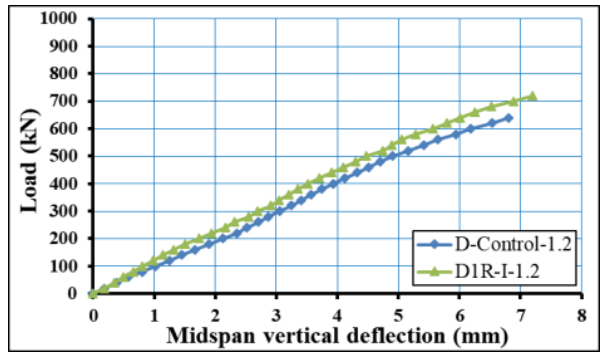

Figure 8 Load-deflection relationship for D-Control-1 and D3RI-I-1

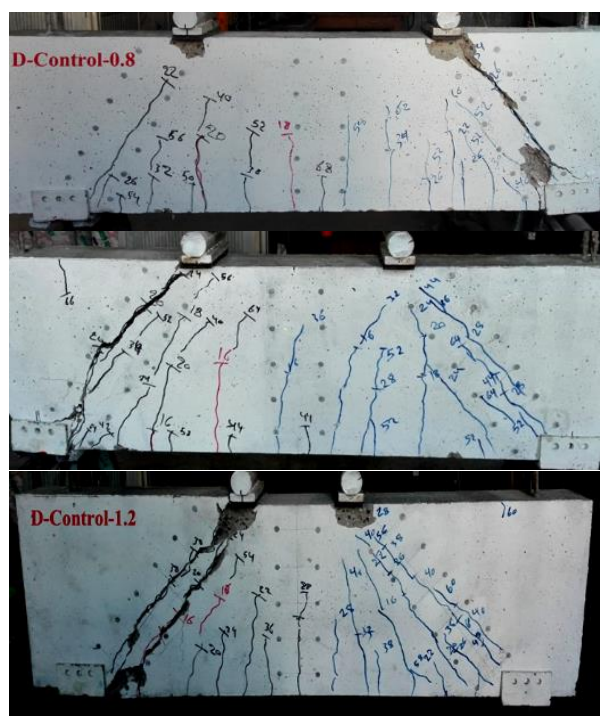

Plate 1 Crack pattern of control beams 


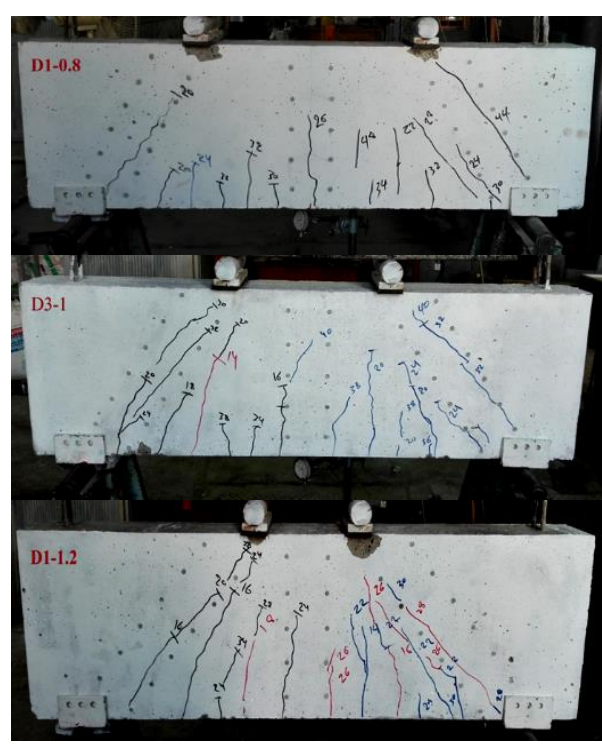

Plate 2 Crack pattern of pre-cracking beams

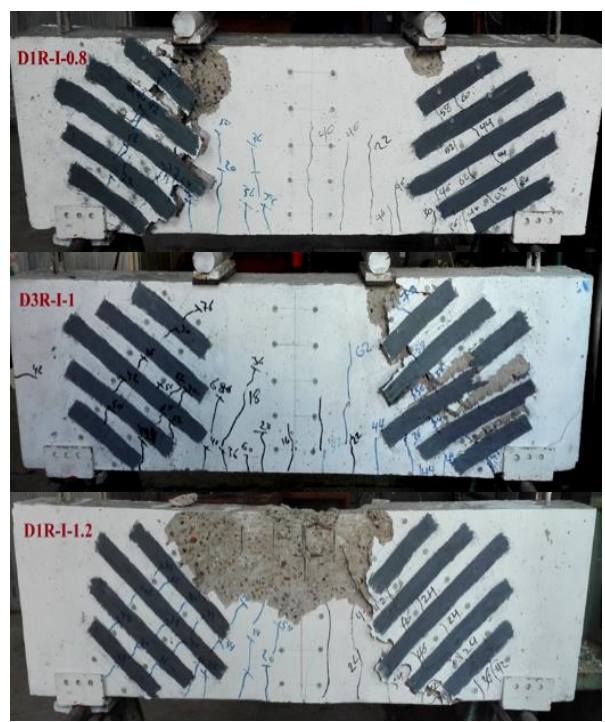

Plate 3 Crack pattern of retrofitted beams

\section{References}

1. ASTM C496 / C496M-04, West Conshohocken, PA: ASTM Int.

2. ASTM C 39 / C 39M-05. Con. and Agg., West Conshohocken, PA, US.

3. ACI 237R-07. ACI Committee 237: Farmington Hills, MI, USA

4. ASTM C78-10, 2010. West Conshohocken, PA: ASTM Int.

5. ASTM A1064 / A1064M-14. West Conshohocken, PA: ASTM Int.

6. ASTM A615 / 615M-14. West Conshohocken, PA: ASTM Int.

7. EFNARC, 2002. 99 West Street, Farnham, Surrey GU9 7EN, UK.

8. Iraqi Standard 5, (1984). Agg. from Natural Sources for Concrete, Baghdad, Iraq.

9. IS (45), (1984). Por. Cement, Central Agency.
10. Stand. and Quality Control, Planning Council, Baghdad, Iraq.

11. Mohammed, A. S., (2016). Build. and Const. Eng. Depart., Uni. of Tech., Baghdad, Iraq, 247 pp.

12. Rasheed, M.M., (2016). Civil and Env. Research, 8, 5, 2, pp. 6-14 